\title{
Assessment of Training Needs of Cashew Farmers in Owan East Local Government Area of Edo State, Nigeria
}

\author{
*Adesiji, G.B, Omotesho, K.F, Bolarin, O. and Aigbavboa, P. \\ Department of Agricultural Economics and Farm Management, University of Ilorin, Ilorin, Nigeria. \\ *Corresponding Author: drgbolaadesij@@yahoo.com
}

\begin{abstract}
The study assessed the training needs of cashew farmers in Owan East Local GovernmentArea of Edo State, Nigeria. Using structured questionnaire, data were collected from eighty (80) randomly selected cashew farmers in five villages of Owan East Local Government Area of Edo State. The findings revealed that the mean age of the respondents was 46.5 years. Majority (87.5\%) of them attended one form of education or the other and about seventy percent of the respondents had been farming for more than 10 years. The tasks performed by the cashew farmers ranged from land preparation to harvesting and storage of farm produce. The study identified strong training needs for cashew farmers in the study area on water management, transplanting, harvesting and storage and nursery preparation. The correlation analysis showed that farming experience had significant relationship with the respondents' training needs $(r=0.489, p=0.05)$. In order to improve performance and increase productivity, adequate training is required for cashew farmers with respect to the identified areas where they indicated needs for training.
\end{abstract}

Keywords: Assessment, Tasks performed, Training Needs, Cashew Farmers, Owan East

\section{INTRODUCTION}

Cashew (Anacardium occidentale L.) is next to cocoa in importance as an export crop and a major source of income to many small holder farmers in the central and northern part of Nigeria. It is a native of Tropical Central and South America, notably North Eastern Brazil, from where it was introduced into Nigeria in the $15^{\text {th }} / 16^{\text {th }}$ century. Nigeria ranked fourth in cashew production among thirteen countries in Africa, having a total area of 100,000 hectares and an average annual production of $80,000 \mathrm{MT}$; thus contributing almost $16 \%$ of the total production of this continent (Krishnaswamy, 2006). However, only $5 \%$ of the global cashew production is from Africa. Cashew fruit has a kidney shape with nut-like seed which is edible when roasted or cooked (New World Encyclopedia, 2008). It is a hardy crop that is tolerant to poor soils and it grows successfully in virtually all agro-ecological zones of Nigeria. According to Ezeagu (2002), cashew is grown in the following states of Nigeria, namely, Abia, Anambra, Benue, Cross-River, Ebonyi, Edo, Ekiti, Enugu, FCT, Kebbi, Kogi, Kwara, Nassarawa Niger, Ogun, Osun, Sokoto and Taraba among others.

The crop is next to cocoa in importance as an export crop and a major source of income to many small scale farmers in the Central and Northern part of Nigeria (Tropper et. al., 2001; CBN, 2005). There 
has been an appreciable increase in price of cashew nuts in the international markets with a ton sold for $\mathrm{N}$ 24,753.00 in 1993 rising to N 180,011.00 in 2003 (Asogwa et.al., 2008).

Ayodele et.al. (2001) postulates 40,000 hectares of total land under cashew cultivation in 1995 of which about $60 \%$ were cultivated by peasant farmers, but which rose to 320,000 hectares in 2006 (FAO, 2007). It was also reported that the production of cashew nut has steadily increased from 30,000 metric tons in 1990 to 636,000 metric tons in 2006 (FAO, 2007) Table 1. In their own report, Aliyu and Hammed (2008) suggest that this significant increase in production has been due mainly to the involvement of the Private Entrepreneurs, Federal and State Governments, Cooperative Societies and Individual Affluent Farmers in cashew production.

Table 1. Cashew Nut Production in Nigeria, 1990-2006

\begin{tabular}{|l|l|l|l|l|}
\hline Year & $\begin{array}{l}\text { Annual production } \\
1000 \text { (tons) }\end{array}$ & Kg/ha & $\begin{array}{l}\text { Harvested area } \\
1000 \text { (ha) }\end{array}$ & Price/tone (A) \\
\hline 1990 & 30.00 & 600.00 & 50.00 & - \\
\hline 1991 & 45.00 & 600.00 & 75.00 & $10,700.00$ \\
\hline 1992 & 55.00 & 611.10 & 90.00 & $15,677.00$ \\
\hline 1993 & 75.00 & 625.00 & 120.00 & $24,753.00$ \\
\hline 1994 & 85.00 & 629.00 & 135.00 & $36,335.00$ \\
\hline 1995 & 95.00 & 612.90 & 155.00 & $62,415.00$ \\
\hline 1996 & 110.00 & 628.60 & 175.00 & $81,872.00$ \\
\hline 1997 & 125.00 & 514.40 & 243.00 & $88,601.00$ \\
\hline 1998 & 152.00 & 625.00 & 243.20 & $94,175.00$ \\
\hline 1999 & $417.00^{\star}$ & $1,752.10^{\star}$ & 248.00 & $92,662.00$ \\
\hline 2000 & 466.00 & $1,799.20$ & 259.00 & $97,407.00$ \\
\hline 2001 & 485.00 & $1,830.20$ & 265.00 & $124,698.00$ \\
\hline 2002 & 514.00 & $1,882.80$ & 273.00 & $150,636.00$ \\
\hline 2003 & 524.00 & $1,891.70$ & 277.00 & $180,011.00$ \\
\hline 2004 & 555.00 & $1,900.70$ & 292.00 & \\
\hline 2005 & 594.00 & $1,922.30$ & 309.00 & \\
\hline 2006 & 636.00 & $1,990.00$ & 320.00 & \\
\hline
\end{tabular}

Source: FAO, 2007

In order to sustain or possibly increase the production capacity of the crop in the country, it becomes highly necessary for its growers, who are mainly the small holder farmers to be adequately trained in their areas of needs. Youdeowei and Kwarteng (2006) defined training need as the difference between the required level of individual competence and his present level of competence. However, Allo 
(2001) suggest that one of the main factors limiting the development of effective training programmes for agricultural professionals in developing countries is the inadequacy of information on their training needs. In view of this constraint, the researcher conducted this study by identifying the training needs for the cashew farmers in the study area.

\section{Objectives of the Study}

The general objective of the study was to assess the training needs of cashew farmers in Owan East Local Government Area of Edo State while the Specific objectives were to:

- $\quad$ examine the socio-economic characteristics of cashew farmers in Owan East Local Government Area of Edo State;

- identify the constraints faced by cashew farmers and

- determine the task areas in which cashew farmers needed further training.

\section{Hypothesis of the Study}

- $\quad H_{0}$ There is no significant relationship between the farmers' socio-economic characteristics and their training needs.

\section{METHODOLOGY}

This study was carried out in Owan East Local Government Area of Edo State. The Local Government has an area of $1,240 \mathrm{~km}^{2}$ and its headquarters is in the town of Afuze. Owan East Local Government Area was purposively selected due to the fact that it is known for cashew production. Multi stage random sampling was used to select five (5) villages out of the twenty seven (27) villages in Owan East Local Government Area. These villages are Afuze, Otou, Uokhai, Oviobumu and Ake. Furthermore, sixteen (16) cashew farmers were randomly selected from each village, thereby giving a total of eighty (80) respondents.

Data were collected with structured questionnaire and analyzed using descriptive statistics such as frequency counts, percentages and means. Correlation analysis was used to test the hypothesis of the study. The training needs were measured by finding first areas where farmers needed training on their jobs using importance of each of the job, difficulty of performance of each job and how frequent these jobs were performed. All these were added together and a mean score of 5.0 and above indicate areas of training needs while a mean score lower than 5.0 indicate areas where trainings are not needed. The jobs were further broken down into tasks and areas where farmers needed training were also identified using the same method. 


\section{RESULTS AND DISCUSSION}

Table 2: Personal Characteristics of Respondents

\begin{tabular}{|l|l|l|}
\hline Variable categories & Frequency & Percentage \\
\hline Age & & \\
\hline $21-40$ & 31 & 38.75 \\
\hline $41-60$ & 34 & 42.50 \\
\hline $61-80$ & 15 & 18.75 \\
\hline Mean age =46.5 & & \\
\hline Gender & & \\
\hline Male & 49 & 61.20 \\
\hline Female & 31 & 38.80 \\
\hline Religion & & \\
\hline Christianity & 72 & 90.00 \\
\hline Islamic & 4 & 5.00 \\
\hline Traditional & 4 & 5.00 \\
\hline Marital Status & & \\
\hline Single & 15 & 18.80 \\
\hline Married & 58 & 72.50 \\
\hline Widowed & 6 & 7.50 \\
\hline Divorced & 1 & 1.20 \\
\hline Educational Status & & \\
\hline No formal education & 5 & 6.25 \\
\hline Adult education & 25 & 31.25 \\
\hline Primary education & 10 & 12.50 \\
\hline Secondary education & 32 & 40.00 \\
\hline Tertiary education & 3 & 3.75 \\
\hline Cashew Farming Experience & & \\
\hline No response & 2 & 2.50 \\
\hline $1-10$ years & 22 & 27.50 \\
\hline $11-20$ years & 28 & 35.00 \\
\hline $21-30$ years & 15 & 18.75 \\
\hline $31-40$ years & 9 & 11.25 \\
\hline Above 40 years & 4 & 5.00 \\
\hline & 80 & 100 \\
\hline Source: Feld & \\
\hline & & \\
\hline & & \\
\hline & & \\
\hline & & \\
\hline & & \\
\hline
\end{tabular}

Source: Field Survey, 2006 
The personal characteristics of respondents are presented in Table 2. A little below average (42.5\%) of the respondents were in the age group of between 41 and 60 years, 38.75\% belonged to age groups of 21-40 years and the remaining $18.75 \%$ were between 61 and 80 years of age. This implies that most of the cashew farmers in the study area were middle-aged.

The distribution based on gender classification revealed that $61.2 \%$ of the respondents were males while $38.8 \%$ were females. The male domination of cashew farming in the study area might be due to off-farm activities of female in buying and selling of farm produce while their male counterparts were highly involved in tree crops production most especially cashew.

The Table also showed that most (72.5\%) of the respondents were married. The Table further revealed that $6.2 \%$ of the respondents did not attend school, while $87.5 \%$ had one form of education or the other. This indicates that the farmers' level of education in the study area is relatively high. It has been observed generally that formal education has a positive influence on the adoption of innovation. Okunlola (2006) also supports this assertion by stating that "education influences various management practices among farmers".

The distribution based on farming experience revealed that $70 \%$ of the respondents have spent above 10 years in cashew production, $27.5 \%$ has Spent less than 10 years while just $2.5 \%$ did not indicate their farming experience. This signifies that majority of the farmers had long time experience in cashew production. The length of service is probably an indicator of a person's commitment to the chosen career (Ejembi et. al., 2006).

Table 3: Distribution based on Farm Size of Cashew

\begin{tabular}{|l|l|l|}
\hline Farm size (ha) & Frequency & Percentage \\
\hline No response & 9 & 11.25 \\
\hline $1-10$ & 22 & 27.50 \\
\hline $11-20$ & 26 & 32.50 \\
\hline $21-30$ & 11 & 13.75 \\
\hline $31-40$ & 6 & 7.50 \\
\hline $41-50$ & 3 & 3.75 \\
\hline Above 50 & 3 & 3.75 \\
\hline & 80 & 100 \\
\hline
\end{tabular}

Source: Field survey, 2006 
The Data in Table 3 showed the respondents' distribution based on farm size. It was revealed that (32.5\%) of the respondents had between $11-20$ hectares, $27.5 \%$ had between $1-10$ hectares, $13.75 \%$ had between 21-30 hectares and 15\% had more than 30 hectares. This implies that the size of cashew farms cultivated in the study area is relatively large, probably because of the high income derived from its sales. This also agrees with the report submitted by Adebiyi et. al. (2008) in a related study that "the sizes of farms cultivated by cashew farmers are increasingly becoming large". However, $11.25 \%$ did not respond which might be due to lack of defined concepts relating to expression of land ownership, sales and purchases (Ekong, 2003).

Table 4: Constraints Facing the Respondents

\begin{tabular}{|l|l|l|}
\hline Constraints & Frequency $(\mathbf{N 0}=\mathbf{8 0})$ & Percentage \\
\hline Inadequate fund & 43 & 53.75 \\
\hline Time & 17 & 21.25 \\
\hline Distance & 10 & 12.50 \\
\hline Insufficient infrastructure & 7 & 8.75 \\
\hline Insufficient chairs & 3 & 3.75 \\
\hline Total & 80 & 100.00 \\
\hline
\end{tabular}

\section{Source: Field Survey, 2006}

The Data in Table 4 identified inadequate funds (53.75\%) as the major constraint faced by the farmers as regards their training. Akinsorotan (1995) opines that there is lack of suitable framework to obtain factual information. 
Table 5: Jobs' Areas Where Training Are Needed

\begin{tabular}{|l|l|l|l|l|}
\hline Job Analysis & Level of importance & Level of difficulties & Frequency & Mean \\
\hline Water management & 1.4 & 3.0 & 1.4 & 5.8 \\
\hline Transplanting & 2.4 & 2.0 & 0.9 & 5.3 \\
\hline Harvesting \& storage & 2.0 & 2.6 & 0.6 & 5.2 \\
\hline Nursery preparation & 1.7 & 2.3 & 1.0 & 5.0 \\
\hline Weeding & 1.3 & 1.4 & 2.0 & 4.7 \\
\hline Pest \& disease control & 1.2 & 3.1 & 0.4 & 4.7 \\
\hline Sowing & 2.0 & 2.1 & 0.3 & 4.4 \\
\hline Nursery maintenance & 1.7 & 1.4 & 1.3 & 4.4 \\
\hline Land preparation & 0.7 & 3.3 & 0.2 & 4.2 \\
\hline Seed selection & 0.8 & 2.3 & 0.4 & 3.5 \\
\hline Total & 15.20 & 23.50 & 8.5 & 47.2 \\
\hline
\end{tabular}

Source: Field Survey, 2006

The entries in Table 5 were arranged in descending order to show where farmers need training. It was shown that farmers need training in the areas of water management, transplanting, harvesting and storage and nursery preparation. Brinkerhoff (2005) posits that training is important in order to improve one's skill on his/her job. 
Adesiji, Omotesho, Bolarin \& Aigbavboa

Table 6: Tasks' Areas Where Training Are Needed

\begin{tabular}{|c|c|c|c|c|}
\hline Farm Activities & Level of Importance & Level of Difficulties & Frequency & Mean \\
\hline \multicolumn{5}{|l|}{ Water Management } \\
\hline Determination of soil composition & 3.3 & 0.9 & 5.2 & 9.4 \\
\hline Availability of water & 5.1 & 1.6 & 2.0 & 8.7 \\
\hline Determination of soil texture & 3.5 & 0.4 & 1.9 & 5.8 \\
\hline $\begin{array}{l}\text { Determination of water retaining } \\
\text { capacity of soil }\end{array}$ & 2.7 & 0.2 & 2.7 & 5.6 \\
\hline Closeness to water supply & 2.6 & 0.9 & 2.5 & 6.0 \\
\hline \multicolumn{5}{|l|}{ Transplanting } \\
\hline Determination of time of transplant & 3.3 & 1.0 & 2.1 & 6.5 \\
\hline Transplanting & 3.0 & 1.4 & 0.4 & 4.8 \\
\hline \multicolumn{5}{|l|}{ Harvesting and storage } \\
\hline Mode of preservation & 5.1 & 0.5 & 0.8 & 6.4 \\
\hline Use of jute bag & 2.5 & 1.6 & 0.5 & 4.6 \\
\hline Drying & 2.0 & 0.9 & 0.9 & 3.8 \\
\hline Determination of harvest time & 0.5 & 0.4 & 0.4 & 2.6 \\
\hline \multicolumn{5}{|l|}{ Nursery preparation } \\
\hline Construction of shade & 3.6 & 2.7 & 0.2 & 6.5 \\
\hline Fumigation & 3.6 & 1.4 & 0.6 & 5.6 \\
\hline Watering & 2.4 & 1.1 & 0.6 & 4.1 \\
\hline Spacing of seed & 2.2 & 1.2 & 0.2 & 3.6 \\
\hline
\end{tabular}

Source: Field Survey, 2006 
Having identified areas of jobs where training was needed, each job is further broken down into tasks and importance, difficulty of performance of each task and how frequent these tasks are performed were measured. A mean score of 5.0 and above indicate areas needed for training while a mean score lower than 5.0 indicates areas where trainings are not needed. Therefore, the Data in Table 6 showed that farmers needed serious training in all activities relating to water management. It also revealed that training is highly needed in the determination of the time of transplanting.

Furthermore, the Table showed that farmers were lacking training in the mode of preservation. Ranaweera and Silva (2000) assert that fruits must be preserved because they are highly perishable. Finally, the entries in Table 6 revealed that farmers need training in the construction of shade and fumigation.

\section{HYPOTHESIS TESTING}

Table 7: Relationship between Training Needs and Socio-economic Characteristics of respondents

\begin{tabular}{|l|l|l|l|l|}
\hline & Age & $\begin{array}{l}\text { Farming } \\
\text { experience }\end{array}$ & $\begin{array}{l}\text { Area of farm } \\
\text { size }\end{array}$ & $\begin{array}{l}\text { Area of cashew } \\
\text { plantation }\end{array}$ \\
\hline Age & 1.000 & $.489^{\star \star}$ & -.150 & -0.91 \\
\hline Farming experience & $.489^{\star *}$ & 1.000 & .107 & -.150 \\
\hline Area of farm size & -.150 & .107 & 1.000 & $.605^{\star *}$ \\
\hline Area of cashew plantation & -0.91 & -.150 & $.605^{\star \star}$ & 1.000 \\
\hline
\end{tabular}

${ }^{\star \star}$ Correlation is significant at 0.05 level and not significant at 0.5 level (2-tailed)

From the hypothesis testing in Table 7, the correlation coefficient for farming experience is 0.489 (i.e. $r=$ $0.489, p=0.05$ ). This signifies that there is significant relationship (though not strong) between training needs of the respondents and their farming experience. Thus, the $\mathrm{H}_{0}(\mathrm{Null})$ hypothesis which states that there is no significant relationship between the training needs of farmers and their socio-economic characteristics is rejected. This result is not unexpected because farmers with higher experience appear to have often full information and better knowledge and are able to evaluate the advantage of any innovation.

However, the ages of the respondents were not significantly related to their training needs $(r=1.000, p=0.05)$. It is possible that age may not be a significant factor in determining training needs. Old 
or young people can be trained or re-trained to enhance their competence on the job (Omoregbee et. al., 2007).

\section{CONCLUSION AND RECOMMENDATIONS}

This study revealed that there is a gap between the present level of competence and the required level of competence of the cashew farmers in the study area. Considering the importance of cashew as an export crop and a major source of income to many small scale farmers, it becomes highly necessary for its growers, who are mainly the small holder farmers to be adequately trained in their areas of needs. This would sustain or possibly increase the production capacity of the crop in the country.

The training must be geared towards the different aspects of activities involved in cashew production in which the farmers indicated incompetence and these are in the areas of water management, transplanting, harvesting and storage of cashew nuts, and nursery preparation.

\section{REFERENCES}

Adebiyi S., E.O. Owagboe, E.A. Agbongiarhuoyi, N. Idris and E.O. Aigbekaen, (2008). "Assessment of Pests and Diseases management Practices among Cashew Farmers in Kogi State, Nigeria". International Journal of Sustainable Agriculture 3(2): 49-53, 2011.

Agbonigiarhuoyi et..al (2007) "Awareness of cashew products potentials and market information among farmers in Kogi state, Nigeria." APRN journal of Agricultural and Biological science 3(4)

Aliyu OM, Hammed LA (2008). Nigerian cashew economy: A review of nut production sector. Paper presented at the International Academy of African Buisiness and Development (IAABD) Conference. University of Florida, Gainesville, USA. May 2024, 2008.

Allo, A.V. (2001). Professional requirements of the extension worker in training the extension worker. FFTC extension bulletin N0.173.

Asogwa, E. U.*, Hammed, L. A. and Ndubuaku, T. C. N.A (2008) "Integrated Production and Protection Practices of Cashew in Nigeria. "African Journal of Biotechnology. 7 (25): 4868-4873

Akinsorotan (1995): "Village Extension Agents Perceptionof the Appraisal Systems in Oyo State Agricultural Development Programme in Nigeria." Journal of Extension Systems (17) 1:59-67 
Ayodele EA, Adebola PO (2001). West African Regional Cashew Survey Report (Guinea, Guinea Bissau, Cote D'Ivore, Ghana and Nigeria). Sustainable Tree Crop Programme (STCP) and Biohybrids Agrisystem Ltd. U.K. 1: 110.

CBN (2005). Central Bank of Nigeria (CBN) Annual report and statement of accounts for the year 2005. 155.Available online@ http://66.40.18.146/search/runsearch.asp.

Ebojei (2007): "Assessment of the Contributions of Bee-keeping Extension Society to the Income of BeeFarmers in Kaduna State" PAT 2008; 4(1): 28-37 ISSN: 0794-5213

Ejembi, E.P; F.E. Omoregbe and S.A. Ejembi, 2006. "Farmers' assessment of the training and visit extension system in central Nigeria: Evidence from Barkin Ladi, Plateau State". Journal of Social Sciences. 12 (3): 201-212.

Ekong E. Ekong (2003). An Introduction to Rural Sociology. Ife Press, Ile-Ife, Nigeria. $2^{\text {nd }}$ Edition, Pp. 88, 2003.

Ezeagu W (2002). Nigeria: Assessment of the situation and development prospects for the cashew nut sector. A report of Nigerian Export Promotion Council (NEPC) submitted to Trade Centre UNCTAT/WTO (ITC) project INT/W3/69. p. 37.

FAO (2007). Food and Agriculture Organization, Statistics Division. Availableonline@http://faostat.fao.org/site/336/DesktopDefault.aspx? PagelD=336

Krishnaswamy (2006) "Nigerian Investment Guide. A bi annual investment journal. Cashew processing in Nigeria" 1(1): 7-8. January-June 2006.

McGee, W. and T. Paul (1961). Training in business and industry. Wiley Publishers, New York: USA. Pp 30-36

New World Encyclopaedia (2008). Cashew from New World Encyclopaedia. Available online@http://www.newworldencyclopedia.org/p/index.php?title Cashew\&oldid=678619.

Ohler JG (1967). "Cashew Growing. Tropical Abstracts (The Netherlands)," 22(1): 1-9.

Ohler JG (1979). Cashew. (Koninklijk Instituut Voo de Tropen:Amsterdam, Netherlands). pp. 260.

Okunlola, J.O (2006): "Factors Associated with Adoption of Food Crops Production Technologies by Small Scale Farmers in Niger Republic." Ogun Journal of Agricultural Production.

Omoregbee (2007): Effect of Agricultural Cooperative membership on Farmer's Income and Poverty in Delta State, Nigeria. 
Ranaweera N and Silva G 2000 'Dynamics of vegetable production, distribution and consumption in Asia' Asian Vegetable Research and Development Centre (AVRDC), Tainan, Taiwan. 2

Venkataramah TM (1976). Cashew nut production and processing Nigeria agronomic aspect of cashew nut production. Unpublished paper submitted to CRIN. Pp39

Youdeowei and Kwarteng 2006.Tools kit for the production of Agricultural Extension materias. Guide book. Wageningen, The Netherlands. :50. 